\title{
THE USE OF JAPANESE ADJECTIVES URESHII AND TANOSHII
}

\author{
Nor Sahayu HAMZAH*1 \\ Zaid MOHD ZIN ${ }^{2}$ \\ Rozita CHE RODI ${ }^{3}$ \\ 1,2,3 Universiti Putra Malaysia, Selangor, Malaysia \\ ${ }^{1}$ norsahayu.hamzah@gmail.com \\ 2zaidmz@upm.edu.my \\ 3ita_cherodi@upm.edu.my
}

Manuscript received 12 April 2020

Manuscript accepted 10 June 2020

*Corresponding author

https://doi.org/10.33736/ils.2353.2020

\begin{abstract}
This study is a semantic study that explores the genre of meaning in general. It focuses on the synonyms of adjectives "ureshii" and "tanoshii" in the construction of sentences in the Japanese language. The objective of this study is to discuss similarities and differences of the usage of synonyms "ureshii" and "tanoshii" and also to analyse the implementation from the perspective of adjectives in the Malay language. The data selected for this study are sentences that contained "ureshii" and "tanoshii" lexicons based on Shinmeikai Japanese Language Dictionary (2012). The data are analysed using textual analysis based on the conceptual framework by Ibrahim Ahmad (2005). The findings of this study elucidate the technical differences in the usage of Japanese adjectives ureshii and tanoshii as compared to Malay adjectives "gembira" [happy] and "seronok" [excited]. It shows that the two adjectives have similar meaning and nuance but cannot be used interchangeably. The outcomes of this study can be used as reference material for teachers and students to master the usage of adjectives in Japanese language. Lastly, further studies on Japanese lexicon "keiyoushi" should be carried out entirely.
\end{abstract}

Keywords: Semantics; Synonyms; Lexical; Japanese Language; Malay Language

\section{Introduction}

The ability of students to construct sentences using suitable lexicon exhibits mastery of the language skills of a particular foreign language. Sillar (1988) states that text, visual and verbal image are an important combination for the process of transmitting, receiving and exchanging information. For that reason, the use of appropriate lexicons in a language needs to be mastered and understood since the meaning of lexicon in the language can be either direct or figurative. The differences 
in lexical meanings that can be found in two language systems had caused mistakes in using the language (Corder, 1973). Synonym or similarity in lexical meanings refer to words that are of different spelling or sound but have similar or nearly identical meanings.

This matter was brought forward by Naila Fauziah (2019) who explained the different function in the usage of lexical items in Japanese language compared to Indonesian language. This leads to mistakes in choosing appropriate lexical items. The construction of grammatical sentences in the Japanese language involves the use of accurate lexicon, correct spelling, appropriate writing selection, and arrangement of the sentence structure following its grammar. The main shortcoming for students in constructing sentences in Japanese language is often observed through their selection of appropriate lexicon. Wijayanti (2018) and Duduong (2018) elucidate that students are often confused in using the correct synonymous lexicon in Japanese sentences because there are variances in the meanings when compared to their native language.

A comparative study in language can be seen from the aspect of using different dialects or languages. There are synonymous lexicons in foreign languages, particularly the Japanese language but they are less likely to be used by the nonnative speakers of the language. This is because there are different characteristics of synonyms that need to be adhered by non-native speakers. Even so, there are synonyms which meanings are easier to comprehend although they are used in diverse contexts by speakers of different demographics. In light of past studies, it is suggested that diversifying lexicon studies that have synonymous meanings in linguistics (Abdullah \& Sahok, 2019).

This study will compare the use of synonymous lexicons in Japanese language with the Malay language. The objectives of the study were to:

1) identify the meaning of synonymous lexicons "ureshii" and "tanoshii" in Japanese language; and

2) discuss the similarities and differences in the use of synonyms ureshii and tanoshii in Malay language.

This study refers only to synonymous lexicons "ureshii" and "tanoshii" in Japanese language. Moroever, the obtained data are referred to Shinmeikai Japanese Dictionary (2012). The meanings of Japanese words are taken from Ichikawa (1997) and Nihongo Goyou Youreibun Kojiten (2005).

\section{Ruigigo in Japanese language}

Synonymy is derived from the ancient Greek word. Syllable "syn" signifies "similar", while "nymy" signifies "name". In other words, synonyms refer to words with similar meaning. In addition, synonyms are not only limited to the lexicons that have similar meaning, but expressions or phrases with similar definition may also indicate synonymous meanings. This suggests that synonyms can be studied by not solely referring to the lexicons but synonymous expressions are also within a similar grouping (Collins Cobuild Advanced Learner's English, 2006). In Japanese language, synonyms are referred to as ruigigo and it is defined as follows: 
一言語体系の語彙のなかで，互いによく似た意味をもつ 2 つ以上の単語.

Two or more words that have similar meaning with each other in the vocabulary of a certain language system.

Japanese Language Education Dictionary (1982)

There are three types of ruigigo:

1) Housetsu Kankei is a type of synonym in which vocabulary meanings have a narrower scope than their vocabulary synonyms. For example, "chichi" and "oya" have similar meaning. However, the meaning of "chichi" refers to "ayah kandung" (biological father), and this word is only used by speaker who is referring to their father in first-person pronoun. Meanwhile, "oya" has a more general meaning wherein it may indicate as "ayah" (father) or "ibu" (mother) or both and they can be used by the speaker as first, second and third-person pronouns.

2) Dougigo is a type of synonymous vocabulary with similar meanings. For instance, both "sakkaa" and "futtobooru" refer to "bola sepak" (soccer), while "pin pon" and "takkyuu" refer to "permainan ping pong" (ping pong game) in Malay language. These "dougigo"-shaped synonyms are usually derived from loanwords that are translated directy from foreign language to Japanese language.

3) Shisateki tokuchou is a type of synonym in which the vocabulary has similar meanings or equivalent with other vocabulary; yet there are differences in their usage.

1)アリさんは冷たい水を飲みます。

Ali san wa tsumetai mizu o nomimasu.

Ali minum air sejuk. [Ali drinks cold water]. $\quad \mathrm{V}$

2)アリさんは 寒い水を 飲みます。 $X$

Ali san wa samui mizu o nomimasu.

Based on Japanese-Malay-English dictionary, "tsumetai" and "samui" lexicons refer to "dingin" (cold) and "sejuk" (cold). However, in Japanese-Indonesia dictionary, the "tsumetai" refers to physical items while "samui" refers to the temperature or weather (Sudjianto, Dian Meilani, \& Andini, 2017).

\section{Adjectives in Japanese Language}

Based on Japanese Language Education Dictionary (1982), adjective or "keiyoushi" is categorised into four characteristics which are trait, colour, situation and emotion and feeling. Keiyoushi are divided into keiyoushi $I$ and keiyoshi $\mathrm{Na}$ (Thaiyibah Sulaiman \& Yoko Kami, 1997). Every lexicon in Japanese language undergoes changes in its form following the time of its usage. Keiyoushi undergoes changes in 
the final syllable for every lexicon of keiyoushi I and keiyoushi $\mathrm{Na}$ as presented in Table 1.

Table 1.

Changes in the lexicon of keiyoushi I and keiyoushi $\mathrm{Na}$

\begin{tabular}{|c|c|c|c|c|}
\hline $\begin{array}{l}\text { Keiyoushi } \\
\text { [形容詞] }\end{array}$ & $\begin{array}{l}\text { Present } \\
\text { Tense }\end{array}$ & $\begin{array}{l}\text { Negative } \\
\text { Present Tense }\end{array}$ & Past Tense & $\begin{array}{l}\text { Negative Past } \\
\text { Tense }\end{array}$ \\
\hline $\begin{array}{l}\text { Keiyoushi i } \\
\text { [い形容詞] }\end{array}$ & $\begin{array}{l}\text { あつい } \\
\text { Atsui } \\
\text { Panas [Hot] }\end{array}$ & $\begin{array}{l}\text { あつくない } \\
\text { Atsukunai } \\
\text { Tidak panas } \\
\text { [Not hot] }\end{array}$ & $\begin{array}{l}\text { あつかった } \\
\text { Atsukatta } \\
\text { Panas [Hot] } \\
\text { (past) }\end{array}$ & $\begin{array}{l}\text { あつくなかった } \\
\text { Atsukunakatta } \\
\text { Tidak panas [Not } \\
\text { hot] } \\
\text { (past) }\end{array}$ \\
\hline $\begin{array}{l}\text { Keiyoushi na } \\
\text { [な形容詞] }\end{array}$ & $\begin{array}{l}\text { しずか } \\
\text { Shizuka } \\
\text { Senyap } \\
\text { [Quiet] }\end{array}$ & $\begin{array}{l}\text { しずかではあ } \\
\text { りません } \\
\text { Shizuka dewa } \\
\text { arimasen } \\
\text { Tidak senyap } \\
\text { [Not quiet] }\end{array}$ & $\begin{array}{l}\text { しずかでした } \\
\text { Shizuka } \\
\text { deshita } \\
\text { Senyap [Quiet] } \\
\text { (past) }\end{array}$ & $\begin{array}{l}\text { しずかではあり } \\
\text { ませんでした } \\
\text { Shizuka dewa } \\
\text { arimasen deshito } \\
\text { Tidak senyap } \\
\text { [Not quiet] } \\
\text { (past) }\end{array}$ \\
\hline
\end{tabular}

\section{Literature Review}

Nursanti and Supriatnaningsih (2019) have found that auxiliary verbs have synonyms with definite meaning in Indonesian language. Their study shows that although these four fukushi have synonyms with similar meanings, there are still differences that confuse the students. For instance, "kanarazu" and "zettai" lexicons have higher levels of "definite" than "kitto" and "zehi" lexicons. "Kanarazu" and "zettai" lexicons are supported with sentences that end with "yo", "darou" and "kamoshiremasen" which further strengthen the speaker's confidence in delivering the information they try to convey to the listener. This study also recommends that the students should scrutinise their sentences comprehensively before selecting the correct lexicon. This is because "kanarazu" lexicon displays certainty near to $100 \%$ to the statement delivered by the speaker (Kobayashi, 1992).

Moreover, Siregar (2018) in a scholarly thesis has discussed keiyoushi Na for "kirai" and "iya". The findings of this study clarify that "kirai" and "iya" lexicons are a part of keiyoushi $\mathrm{Na}$ that have synonymous meanings. These lexicons have similar meaning in which they are referring to the feeling of hate or unpleasantness. However, the use of "kirai" and "iya" lexicons is dissimilar depending on the context of the sentence. Generally, "kirai" lexicon refers to the meaning that possesses strong feelings such as dislike, unpleasant, reluctant and hate. Meanwhile, "iya" lexicon has multiple meanings which includes strong feeling 
of distasteful that refers to food; discomfort referring to situation; disgust referring to one's behaviour; as well as frustration to terrible act in Indonesian language.

Furthermore, Siagian (2018) has concluded that "yaru and "suru" verbs are synonyms in Indonesian language vocabulary which refer to an act of doing or working. The outcome of this thesis also elucidates the function differences in the use of "yaru" and "suru". "Suru" lexicon can be used to refer to the meaning of an act of doing something and demonstrating behaviour. Meanwhile, "yaru" lexicon refers to the meaning of presenting a decision or presenting a situation in Indonesian language. This study also suggests that even though these two lexicons are synonymous, academics and students should be more meticulous in their interpretation of using them in Japanese sentences.

In contrast to Kim (2018) with research entitled Mikaku O Hyougen Suru Keiyoushi no Imi Kouzou to Goi Taikei, it looks at keiyoushi lexicon in the use of taste adjective and has suggested a new system of division for the original keiyoushi characteristics. Researchers have proposed that there is a need for division in keiyoushi lexicon between sensory and emotion characteristics. The findings of the study show that the features of taste perception refer to the sensory characteristic such as "nigai", "sibui", "amai" and "karai" and they are also important in interpreting one's emotion. For instance, "nigai" lexicon, which means bitter, can be used when a person has tasted a certain component in foods or drinks that causes a person to be physically disturbed and thus producing unpleasant feeling to the person emotionally. Meanwhile, experience that is associated with "nigai lexicon refers to the attitude characteristic which gives discomfort to the person psychologically. These synonymous lexicons function as a description of one's sensory and emotion characteristics. The explanation for sensory perception is influenced by physical causes, while emotion expressions are influenced by individual's psychological discomfort.

Lastly, Putri (2018) in a study of lexicon "Utsukushii" and "Kirei" have discussed the similarities of the meanings by comparing the meanings of vocabulary "beautiful", "pretty", "good", "kind", and "vibrant/refined" in Indonesian language. The study shows that there are four different usages in the function of these lexicons. "Utsukushii" lexicon focuses on the subject as the main topic while also in abstract form or collaborative connection which also means harmony in Indonesian language. Whereas, "kirei" lexicon focuses on the subjects related to color, gas, or imperceptible things. Additionally, "kirei" lexicon is used to describe skills regarding to a game as a measuring device.

\section{Method of the Study}

In the process of learning Japanese language, students encounter Japanese synonymous lexicons that have smilar meaning in Malay language. For example, "tsumetai" and "samui" have a synonymous meaning to "sejuk" (cold) in Malay language. However, non-native speakers or students might find it difficult to understand the similarities and differences and also the contexts needed for using "tsumetai" or "samui" lexicons in Japanese language. The speakers or students' shortcoming in mastering the use of lexicon following the right circumstances 
prompted them to make mistakes in the sentence construction. Based on these circumstances, a form of a descriptive and qualitative study focuses on the comparison between "ureshii" and "tanoshii" lexicons in Malay language. The analysed data are sentences that included "ureshii" and "tanoshii" lexicons are obtained from the Shinmeikai Japanese Language Dictionary (2012). The study utilises interlingual comparative method between Japanese language and Malay language. In addition, the data of this study are analysed using Ibrahim Ahmad's (2005) conceptual framework which outlines five different characteristics of synonyms:

1) The difference in dialect.

2) The difference in formal phase.

3) The difference in the use of technical words.

4) The difference in connotation.

5) The difference in the use of euphemism.

\section{Results}

Kamus Linguistik (1997) defines synonyms as two or more words that have similar or nearly equivalent meaning in a language. Hence, the meaning connection between two synonymous lexicons are considered to be bilateral (Verhaar, 1978).

\section{Synonyms of ureshii and tanoshii in the Japanese Language}

Ureshii lexicon in Japanese language may be translated as:

自分の欲求が満足されたと感じで、その状態を積極的に受け入れょうとす ると気持ちだ。

A feeling when one's desire is satisfied and they are ready to accept the condition.

Shinmeikai Japanese Language Dictionary (2012)

The definition of "ureshii" lexicon according to Shinmeikai Japanese Language Dictionary (2012) refers to the emotion characteristic through self-interest while also being satisfied with the situation. In addition, the lexicon also explicates that the individual is ready to accept the situation which indicates that the happiness caused by external events is only momentary. The following are sentences which utilised ureshii lexicon based on the data obtained from Shinmeikai Japanese Language Dictionary (2012):

1)あの人に 会えて 嬉しかった。 Ano hitoni aete ureshikatta.

Saya gembira dapat berjumpa dengan orang itu.

[I am happy to meet that person.] 
2) 明日 休みだ、嬉しいなあ。 Ashita yasumida. Ureshiinaa.

Esok cuti, (saya) gembiranya.

[Holiday tomorrow, (I) am happy.]

Esok cuti, gembiranya.

[Holiday tomorrow, happy.]

3） 4 月から 自分も 大学に 入るかと思うと、何となく 嬉 しい気持ちになる。

Shigatsu kara jibunmo daigakuni hairuka toomou to, nantonaku ureshii kimochi ni naru.

(Saya) merasa gembira kerana bulan April saya akan masuk ke universiti.

[(I) feel happy because in April, I will enroll at the university]

Tanoshii "lexicon" in Japanese Language may be translated as:

充足感があじわえるものとして、その状態を積極的に受け入れたい、 出来ることならそれを気持ちだ。

A feeling when one has a pure satisfaction and they accept the condition completely.

The characteristic of "tanoshii" lexicon indicates the feeling of joy or excitement that comes within self and that feeling persists over time. The following are sentences that utilised "tanoshii" lexicon based on the data obtained from Shinmeikai Japanese Language Dictionary (2012):

4) 狭いながらも 楽しい我が家。

Semai nagaramo tanoshii wagaya.

(Kami) seronok walaupun rumah sempit (kecil).

[(We) are excited even though our house is small]

5) 気の合った 友人と楽しい一時を過ごす。

Ki no atta yuujin to tanoshii hito toki o sugosu.

(Saya) rasa seronok meluangkan masa bersama kawan baik.

[(I) feel excited when spending time with best friend.]

6) たのしい ショッピング。

Tanoshii shopinggu.

Membeli belah yang seronok.

[Exciting shopping.] 
However, these "ureshii" and "tanoshii" lexicons indicate that feeling of happiness and excitement can only be used in situations by speakers when using first-person pronoun. Meanwhile, in the case of second-person pronouns, it can only be used as question form, Thaiyibah Sulaiman and Yoko Kami (1997).

\section{Similarities and differences in the use of synonymous lexicons ureshii and tanoshii in Japanese language.}

Semantically, keiyoshi I are divided into two parts where the first part of keiyoshi I expresses condition or attitude in objective form while the second part of keiyoshi I denotes emotion and sensory perception in subjective form. In this study, the meaning of "tanoshi" and "ureshii" lexicons are situated in the second part of keiyoshi I where it shows emotion and sensory perception that are in subjective form. This division of Keiyoshi I has differences in terms of its usage compared to Malay language. This is because there are two common questions in the structure of Japanese sentences which are:

1. Who is feeling such way?

2) What is the object/item/matter that causes such feeling?

Henceforth, this study will also discuss the questions of (1) who is feeling such way? and (2) what is the object/item/matter that causes such feeling? This type of keiyoshi I can only be used by first-person pronoun while for the second-person pronoun, it can only be utilised in the form of question. This is because keiyoshi $l$ is related to the emotion and sensory perception that only the individual can experience, whereas for the others, they can only guess or assume the situation merely on the surface level. Examples are shown in Excerpts 7-9:

7) 私は 嬉しいです。

Watashi wa ureshii desu.

Saya berasa gembira.

[I feel happy.]

8)あなたは 嬉しいですか。

Anata wa ureshii desuka.

Awak gembira?

[Are you happy?]

9) あの女の子は嬉しがっています。

Ano onnano ko wa ureshigatte imasu.

Budak perempuan itu kelihatan gembira.

[That girl seems happy.]

Excerpt 7 describes the feeling of happiness as required by the question (1) who is feeling such way? The "I" refers to the first-person pronoun. Meanwhile, Excerpt 8 shows a situation referring to the question (2) what is the 
object/item/matter that causes such feeling? If the sentence in Excerpt 7 is made into a statement such as “Anatawa ureshii desu”. (あなたは嬉しいです。) (Awak gembira; You are happy), this sentence becomes an unusual form of structure in the Japanese language. A similar error will be made if it were replaced with tanoshii lexicon. For Excerpt 9, ureshii and tanoshi lexicons are not used directly into the sentence. In contrast, the sentence has an addition of an end suffix -garu [ $\sim$ が る] which precedes keiyoshi I by dropping the I [ $]$ ]. The addition of suffix -garu [ が る] indicates emotion or desire of others referred by the speaker. In this case, the speaker refers to "Ano onnano ko" [あの女の 子], (budak perempuan itu; the girl).

Therefore, "ureshii" and "tanoshi" lexicons of keiyoshi I refer to the feeling of happiness and excitement which only the speaker can use for themselves. However, "ureshii" lexicon requires secondary factor in inducing these feelings; as exemplified by Excerpts 10-12:

10)久しぶりに 孫の顔を見ることが出来て、とても 嬉しかった。

Hisashiburini mago no kao o miru kotoga dekite, totemo ureshikatta.

(Saya) sangat gembira kerana dapat melihat (wajah) cucu setelah sekian lama. (tidak berjumpa).

[(I) feel excited seeing my grandchild's face after a while (not meeting)].

11) 今日から 春休みなので、とても嬉しい Kyou kara haruyasumi nanode, totemo ureshii.

(Saya) sangat gembira kerana hari ini bermula cuti musim bunga.

[(I) am so happy because spring break starts today.]

12)ずっと＼cjkstart欲しかった洋服が買えたので、嬉しい気持ち になった。

Zutto hoshikatta youfuku ga kaeta node, ureshii kimochi ni natta.

(Saya) rasa gembira kerana pakaian yang diinginkan telah dapat dibeli.

[(I) feel happy because I get to buy the clothes, I have desired.]

Excerpt 10 refers to the speaker's feeling of happiness who wants to see their grandchild. Then in Excerpt 11, the feeling of happiness is because the spring break has begun, and in Excerpt 12, it refers to a person's happiness whom desired clothes have been bought and owned. All of the examples refer to the external sources that become the secondary factors of excitement to the speaker. According to these examples, the feeling of excitement only arises when external factors influence it as shown in Table 2. Based on Table 2, Japanese "ureshii" lexicon is defined as "gembira" (happy) and "tanoshii" is defined as "seronok" (excited). "Gembira" lexicon is an adjective where it reflects emotion characteristic in Malay language and also synonymous with "seronok" lexicon. Furthermore, "seronok" lexicon is translated as a pleasant or heart-warming feeling. Meawnhile, from the sensory perception, it reflects something that is pleasant to hear and also beautiful to see. This lexicon is also described as a matter or situation that can be exciting and 
heart-warming, Kamus Dewan Edisi Keempat (2019). The use of "gembira" and "seronok" lexicons in Malay language are exchangeable in sentences as shown in Table 3.

Table 2

Secondary factors for the use of ureshii [嬉 L ( ) lexicon

\begin{tabular}{lll}
\hline Sentence & Ureshii [嬉しい] & Secondary Factor \\
\hline J & Gembira (Happy) & Meeting grandchild \\
K & Gembira (Happy) & The arrival of spring break \\
L & Gembira (Happy) & Buying clothes \\
\hline
\end{tabular}

Table 3.

The use of gembira and seronok lexicons in Malay language

\begin{tabular}{|c|c|c|}
\hline No. & Japanese Sentences & Malay Sentences \\
\hline 1 & 私は嬉しいです。 & $\begin{array}{l}\text { Saya berasa gembira. [I feel happy]. } \\
\text { Saya berasa seronok. [I feel excited]. }\end{array}$ \\
\hline 2 & あなたは嬉しいですか & $\begin{array}{l}\text { Awak gembira? [Are you happy?]. } \\
\text { Awak seronok? [Are you excited?]. }\end{array}$ \\
\hline 3 & $\begin{array}{l}\text { あの女の子は嬉しがっ } \\
\text { ています。 }\end{array}$ & $\begin{array}{l}\text { Budak perempuan itu kelihatan gembira. } \\
\text { [The girl seems happy]. } \\
\text { Budak perempuan itu kelihatan seronok. } \\
\text { [The girl seems excited]. }\end{array}$ \\
\hline 4 & $\begin{array}{l}\text { 久しぶりに孫の顔を見 } \\
\text { ることが出来て、とて } \\
\text { も嬉しかった。 }\end{array}$ & $\begin{array}{l}\text { (Saya) sangat gembira dapat melihat wajah } \\
\text { cucu saya selepas sekian lama (tidak berjumpa.) } \\
\text { [(I) feel happy seeing my grandchild's face after } \\
\text { a while (not meeting)]. } \\
\text { (Saya) sangat seronok melihat (wajah) cucu } \\
\text { saya selepas sekian lama (tidak berjumpa.) } \\
\text { [(I) feel excited seeing my grandchild's face } \\
\text { after a while (not meeting)]. }\end{array}$ \\
\hline 5 & $\begin{array}{l}\text { 今日から春休みなので } \\
\text { 、とても嬉しい。 }\end{array}$ & $\begin{array}{l}\text { (Saya) sangat gembira kerana hari ini bermula } \\
\text { cuti musim bunga. } \\
\text { [(I) feel happy because today starts the spring } \\
\text { break]. } \\
\text { (Saya) sangat seronok kerana hari ini bermula } \\
\text { cuti musim bunga. } \\
\text { [(I) feel excited because today starts the spring } \\
\text { break]. }\end{array}$ \\
\hline 6 & $\begin{array}{l}\text { ずっと欲しかった洋服 } \\
\text { が買えたので、嬉しい } \\
\text { 気持ちになった。 }\end{array}$ & $\begin{array}{l}\text { (Saya) rasa gembira kerana dapat pakaian yang } \\
\text { diinginkan telah dapat dibeli. } \\
\text { [(I) feel happy because my desired clothes have } \\
\text { been bought]. } \\
\text { (Saya) rasa seronok kerana dapat pakaian yang } \\
\text { diinginkan telah dapat dibeli. }\end{array}$ \\
\hline
\end{tabular}


[(I) feel excited because my desired clothes have been bought].

\section{Conclusion}

In conclusion, "ureshii" and "tanoshii" lexicons in Japanese language have similar meaning and also synonymous. The "ureshii" lexicon means "gembira" (happy) and displays emotion characteristic that is temporary in a specific period and requires the presence of external factors to induce the feeling of happiness. Whereas "tanoshii" lexicon that means "seronok" (excited) is summed up as emotion characteristic that is expressed from within the individual without any external factors to induce the presence of such feeling. In addition, the feeling displayed is continuous and long-lasting. Based on Ibrahim Ahamd's (2005) conceptual framework, the difference feature of the synonyms "ureshii" and "tanoshii" lexicons in Japanese language is the third feature which is the difference in the use of technical words or also known as vocabulary technical at jargon, which is used in many different fields or professions. Technically in Japanese, "ureshii and "tanoshii" lexicons have the similar definition and meaning but they can not be used in all sentences compared to the "gembira" and "seronok" lexicons in Malay language.

Furthermore, the present study can be extended to other "keiyoushi" lexicons in Japanese language in order to see more similarities and differences in the characteristics of adjectives in Malay language. The research data can be further expanded by analysing short stories or novels in both languages. The construction of grammatical sentences in the Japanese language involves using the use of accurate lexicon, correct spelling, appropriate writing selection, and arrangement of the sentence structure following its grammar. The main shortcoming for students in constructing sentences in Japanese language is often observed through their selection of appropriate lexicon. Wiyayanti (2018) and Duduong (2018) elucidate that students are often confused in using the correct synonymous lexicon in Japanese sentences because there are variances in the meanings when compared to their native language. Therefore, this study looks at the use of synonymous lexicons that have the same meaning but cannot be used for all context in sentences.

Also, a comparative study in language can be seen from the aspect of using different dialects or languages. There are synonymous lexicons in foreign languages, particularly the Japanese language but they are less likely to be used by the nonnative speakers of the language. This is because there are different characteristics of synonyms that need to be adhered by non-native speakers. Even so, there are synonyms which meanings are easier to comprehend although they are used in diverse contexts by speakers of different demographics. In light of past studies, it is suggested that diversifying lexicon studies that have synonymous meanings in linguistics (Siti Abdullah \& Jais Sahok, 2019). 


\section{References}

Duduong, J. (2018) Analisis makna dan penggunaan "Iroiro-Na Dan Samazama-Na" dalam kalimat Bahasa Jepang. Jurnal Elektronik Fakultas Sastra Universitas Sam Ratulangi, 1(1), 1-13.

Fatin Nadirah, \& Mohd Yusof (2018). Negative transfer in second language writing among Malay university students. (Tesis Sarjana). University of Malaya, Kuala Lumpur, Malaysia.

Ibrahim Ahmad. (2002). Perkamusan Melayu: Suatu pengenalan. Kuala Lumpur, Malaysia: Dewan Bahasa dan Pustaka.

Ichikawa, E. (1997). Nihongo Goyou Youreibun Kojiten = Dictionary of Japanese

Ikita Reibun De Manabu Nihongo Hyougen Bunkei Jiten, “生きた”例文で学ぶ日本 語表現文型辞典. (2005). アスク出版編集部.

Kamus Dewan Edisi Keempat (2015). Kuala Lumpur. Dewan Bahasa dan Pustaka

Kamus Linguistik. (1997). Kuala Lumpur. Dewan Bahasa dan Pustaka

Kamus Pelajar Edisi Kedua (2015). Kuala Lumpur. Dewan Bahasa dan Pustaka

Kobayashi, N. (1992).「必ず・確かに・確か・きっと・ぜひ」の意味分析. Journal of Japanese language teaching, (7), 1-17.

Naila Fauziah (2019). Analisis kontrastif ungkapan keharusan dalam Bahasa Jepang ( Nakerebanaranai, Naitoikenai) dan harus dan mesti dalam Bahasa Indonesia. (Tesis Sarjana Universitas Pendidikan Indonesia). Bandung, Indonesia.

Nursanti, A., \& Supriatnaningsih, R. (2019). Analisis kesalahan penggunaan Fukushi Kanarazu, Kitto, Zettai (Ni) dan zehi pada mahasiswa prodi pendidikan bahasa Jepang UNNES. CHI'E: Jurnal Pendidikan Bahasa Jepang, 7(2), 59-62.

Putri, I. (2019). Sinonim adjektiva utsukushii dan kireida dalam bahasa Jepang: Kajian Semantik. Jurnal SORA, 3(2), 90-101.

Siagian, B. (2018). Analisis fungsi dan makna verba yaru dan suru sebagai sinonim. (Tesis Sarjana). Universiti Sumatera Utara. Medan, Indonesia.

Sinclair, J. (2006). Collins Cobuild advanced learner's English dictionary. Glasgow: HarperCollins.

Siregar, H. A. (2018). Analisis nuansa makna sinonim kirai dan iya dalam komik "Kekkon Shiyouyo". (Tesis Sarjana). Universitas Sumatera Utara. Medan, Indonesia.

Siti Abdullah, \& Jais Sahok. (2019). Sinonim leksikal dalam bahasa Iban dan Salako. Sains Humanika, 11(2), 35-45.

Sudjianto, Dian Meilani, \& Andini (2017). Kamus Jepang-Indonesia. Jakarta Selatan. KAWAHMedia.

Thaiyibah Sulaiman \& Yoko Kami (1997). Nahu Bahasa Jepun. Kuala Lumpur: Dewan Bahasa dan Pustaka.

Verhaar, J.W.M. (1978). Pengantar linguistik Jilid I. J.W.M. Yogyakarta: Gadjah Mada University Press.

Wijayanti, P. (2018). Penggunaan ungkapan meminta maaf dan berterima kasih sebagai respon dalam bahasa Jepang serta pendekatan yang tepat dalam pembelajarannya. E- Jurnal Mitra Pendidikan, 2(8), 853-866. 